\title{
Interactive effects of cadmium and copper on metal accumulation, oxidative stress, and mineral composition in Brassica napus
}

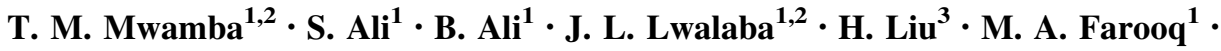 \\ J. Shou ${ }^{4} \cdot$ W. Zhou ${ }^{1}$
}

Received: 1 February 2016/Revised: 2 May 2016/Accepted: 1 June 2016/Published online: 27 June 2016

(C) Islamic Azad University (IAU) 2016

\begin{abstract}
Heavy metals' frequent occurrence and toxicity caused considerable concerns in assessing the interactive effects of metals on exposed plants. Therefore, a hydroponic study was conducted to assess the growth response and physio-chemical changes in Brassica napus plants under single and combined stress of two environmentally alarming metals $(\mathrm{Cd}$ and $\mathrm{Cu}$ ). Results showed that 15-day metal exposure to different metal concentrations $(0,50$, $200 \mu \mathrm{M})$ significantly enhanced $\mathrm{Cd}$ accumulation, while lesser extent of $\mathrm{Cu}$ was observed in plant tissues. Nonetheless, $\mathrm{Cu}$ caused more pronounced oxidative damages and plant growth retardation. Both metals showed similar trend of changes in mineral composition, although $\mathrm{Cu}$ proved more damaging effect on $\mathrm{K}$ and $\mathrm{Mn}$ contents, and $\mathrm{Cd}$ on $\mathrm{Zn}$ contents. In combined treatments, $\mathrm{Cd}$ stimulated $\mathrm{Cu}$ uptake, notably at low concentration, while its own uptake was restricted by the presence of $\mathrm{Cu}$. At either level of concentration, combined stress of these metals exacerbated plant growth inhibition and caused further
\end{abstract}

\footnotetext{
H. Liu

ren.n@163.com

W. Zhou

wjzhou@zju.edu.cn

1 Institute of Crop Science and Zhejiang Key Laboratory of Crop Germplasm, Zhejiang University, Hangzhou 310058, China

2 Department of Crop Science, Faculty of Agriculture, University of Lubumbashi, P.O. Box 1825, Lubumbashi, Democratic Republic of the Congo

3 College of Agriculture and Food Science, Zhejiang A \& F University, Lin'an 311300, China

4 Zhuji Municipal Agro-Tech Extension Center, Zhuji 311800 , China
}

oxidative damages compared to their individual stress. However, metals synergistic effects occurred only in conditions where $\mathrm{Cu}$ uptake was enhanced by $\mathrm{Cd}$. A greater synergistic effect was observed in sensitive cultivar Zheda 622 as compared to the tolerant cultivar ZS 758. As to mineral composition, no metals synergistic effects were noted. This study highlighted the ecotoxicological significance of Cd-led $\mathrm{Cu}$ uptake in B. napus, which was assumed to drive metals' synergistic toxicity, and showed that the relationship between $\mathrm{Cd}$-led $\mathrm{Cu}$ uptake and plant growth responses could vary with respect to cultivar.

Keywords Accumulation - Brassica napus L. Cadmium · Copper · Interaction · Synergistic effects

\section{Introduction}

Increasing metals accumulation in soil, originated from growing industrial activity, intensive use of fertilizers and improper disposal of wastes, has become a prevalent environmental issue in the modern era (Smith 2009; Kabata-Pendias 2011). Cadmium (Cd) and copper $(\mathrm{Cu})$ are among elements of most concern as they can reach high level in soil due to their frequent occurrence and high contents in common sources of soil contamination (Kikuchi et al. 2007; Nagajyoti et al. 2010). In China for instance, as a result of only two decades of industrialization and urbanization, $\mathrm{Cd}$ and $\mathrm{Cu}$ concentrations have reached higher levels than their background values in soil, even in agricultural ones (Wei and Yang 2010).

Higher concentrations of both $\mathrm{Cd}$ and $\mathrm{Cu}$ are toxic and critical constraints in limiting the crop productivity worldwide. Though, $\mathrm{Cu}$ is normally essential for many physiological processes in plants (Burkhead et al. 2009), 
but become strongly phytotoxic in excess amount since the redox properties that account for its essential role, also contribute to its toxicity (Cuypers et al. 2011). By contrast, $\mathrm{Cd}$ has no known physiological functions in plant metabolism, except for some Cd-hyperaccumulating populations that presumably require $\mathrm{Cd}$ for normal growth (Verbruggen et al. 2009). Nonetheless, due to its chemical similarity with essential bivalent cations, $\mathrm{Cd}$ is also largely absorbed by plants (Lin and Aarts 2012). Toxic levels of these metals cause over-production of reactive oxygen species (ROS) (Gill and Tuteja 2010), leading to irreversible structural damages to cellular components and severe impairment of important physiological processes in plants such as photosynthesis, respiration, and the metabolism of essential elements (Ali et al. 2013a, b; Andresen and Küpper 2013; Ravet and Pilon 2013).

$\mathrm{Cd}$ and $\mathrm{Cu}$ continuously added into the agricultural soils through common source including inorganic fertilizers, sewage sludge, irrigation water, and pesticides (de LópezCamelo et al. 1997; Nagajyoti et al. 2010; Wuana and Okieimen 2011). Consequently, the toxic effects of the two metals are likely occurred simultaneously, particularly in acidic soils where their environmental availability increases with a decrease in soil pH (Guo et al. 2007; KabataPendias 2011). It is thus necessary and important to assess the growth responses of plants to the combined toxic effects of $\mathrm{Cd}$ and $\mathrm{Cu}$, which not only reflects real-life exposure of organisms (An et al. 2004), but also considers the fact that components of chemical mixture may interact in a fashion that affects each other's toxicity (Spurgeon et al. 2010). The significance of this approach drawing on such scientific attention and paying appropriate attention to the interactive toxicity of chemicals in the environment (Ali et al. 2011; Oliveira et al. 2014; Wu et al. 2014; Islam et al. 2015; Liu et al. 2015).

In the current context of widespread metals contamination, tremendous efforts have been put in identifying suitable plants to grow in contaminated soils, which highlighted the environmental importance of oilseed rape (Yadav and Srivastava 2014), a species historically grown for its edible oil (Zhou 2001). The interest in this species is derived from its properties of rapid growth, high biomass production, and relative resistance to metal stress ( $\mathrm{Yu}$ et al. 2012), which made it a candidate plant for phytoremediation, along with species like B. juncea, Helianthus annuиs, and Zea mays (Yadav and Srivastava 2014). Despite such importance, however, little is known about the toxicity response of Brassica napus plants against metal mixture stress and the interactive toxic effects of $\mathrm{Cd}$ and $\mathrm{Cu}$, although extensive literature exist on individual response of $\mathrm{Cd}$ and $\mathrm{Cu}$ stress on plants (Burkhead et al. 2009; Ali et al. 2014; Andresen and Küpper 2013; Ravet and Pilon 2013). A few studies have previously investigated the combined toxicity of $\mathrm{Cd}$ and $\mathrm{Cu}$ in terrestrial plants including B. chinensis (Wong et al. 1986), Picea sitchensis (Burton et al. 1986), carrot (Al-Subu et al. 1993), cucumber (An et al. 2004), and more recently barley (Žaltauskaité and Šliumpaitè 2013), but pretty varied trend of results have been obtained. This could be suggestive of speciesdependent growth responses of plants to the combined stress of $\mathrm{Cd}$ and $\mathrm{Cu}$; accordingly, specific toxicity responses could be expected for B. napus.

In prospect of efficient use in phytoremediation, there is an obvious need to understand the toxicological implications associated with growing B. napus in co-contaminated media of $\mathrm{Cd}$ and $\mathrm{Cu}$. The present study was carried out as an effort to fill this gap, using plant growth, oxidative stress and mineral composition as toxicity endpoints in relation to the pattern of metal bioaccumulation. In this study, two B. napus cultivars differing in metals tolerance were selected to test the hypothesis of genotype-dependent toxicity response.

\section{Materials and methods}

\section{Plant materials and growth conditions}

Seeds of two leading oilseed rape (B. napus L.) cultivars (cvs. Zheda 622 and ZS 758) earlier detected as differing in metals tolerance (Farooq et al. 2015; Gill et al. 2015) were obtained from the College of Agriculture and Biotechnology, Zhejiang University, and used in this study. Mature seeds were germinated in plastic pots $(170 \mathrm{~mm} \times 220 \mathrm{~mm})$ filled with peat soil. Four-week-old seedlings were selected for morphological uniformity and transferred to 5 -L black plastic pots containing $4.5 \mathrm{~L}$ nutrient solution prepared (in $\mu \mathrm{M}$ ) as follows: $4000 \mathrm{Ca}\left(\mathrm{NO}_{3}\right)_{2} \cdot 4 \mathrm{H}_{2} \mathrm{O}, 4000\left(\mathrm{NH}_{4}\right)_{2} \mathrm{SO}_{4}, 4000$ $\mathrm{K}_{2} \mathrm{SO}_{4}, 4000 \mathrm{KNO}_{3}, 1300 \mathrm{KH}_{2} \mathrm{PO}_{4}, 1000 \mathrm{MgSO}_{4} \cdot 7 \mathrm{H}_{2} \mathrm{O}, 50$ Fe-EDTA, $10 \mathrm{H}_{3} \mathrm{BO}_{3}, 5 \mathrm{MnSO}_{4} \cdot \mathrm{H}_{2} \mathrm{O}, 5 \mathrm{ZnSO}_{4} \cdot 7 \mathrm{H}_{2} \mathrm{O}, 1$ $\mathrm{CuSO}_{4} \cdot 5 \mathrm{H}_{2} \mathrm{O}$, and $0.5 \mathrm{Na}_{2} \mathrm{MoO}_{4} \cdot 2 \mathrm{H}_{2} \mathrm{O}$. Three plants per pot were plugged into evenly spaced holes on the pot cover and placed under ambient conditions $\left(20-24{ }^{\circ} \mathrm{C}\right.$ temperature and 55-60\% relative humidity) in a green house. After 8 days of plants acclimatization, $\mathrm{Cd}$ as $\mathrm{CdCl}_{2} \cdot 2.5 \mathrm{H}_{2} \mathrm{O}$ and $\mathrm{Cu}$ as $\mathrm{CuCl}_{2} \cdot 2 \mathrm{H}_{2} \mathrm{O}$ were applied to desired concentrations either individually or in equimolar mixture, to make the following treatments: (1) Control; (2) $50 \mu \mathrm{M} \mathrm{Cd}$; (3) $50 \mu \mathrm{M} \mathrm{Cu}$; (4) $50 \mu \mathrm{M} \mathrm{Cd}+50 \mu \mathrm{M} \mathrm{Cu}$; (5) $200 \mu \mathrm{M} \mathrm{Cd}$; (6) $200 \mu \mathrm{M} \mathrm{Cu}$; and (7) $200 \mu \mathrm{M} \mathrm{Cd}+200 \mu \mathrm{M} \mathrm{Cu}$. The treatment concentrations were based on findings from pre-experimental studies, in which several lower and higher levels of $\mathrm{Cd}$ and $\mathrm{Cu}$ were used, that is, 25, 50, 100, 200, and $400 \mu \mathrm{M}$. Both metals at concentration of $50 \mu \mathrm{M}$ showed little damage to plant growth and $200 \mu \mathrm{M}$ imposed significant damage to plant growth, whereas concentrations higher than $200 \mu \mathrm{M}$ were too toxic for plant growth. The $\mathrm{pH}$ of solution was 
maintained at $5.7 \pm 0.1$ with $1 \mathrm{M} \mathrm{NaOH}$ or $\mathrm{HCl}$ solution. Aeration was given continuously through air pump in the nutrient medium. Nutrient solution was changed after every 4 days, but $\mathrm{pH}$ of solution was readjusted on daily basis. The study was laid out in a completely randomized design with three replicates. Fifteen days after treatment, all morphological data were measured and plants roots were thoroughly washed with deionized water to remove surface ions. Then, samples were collected for physiological and biochemical analysis as below. With respect to laboratory assay, samples were collected either fresh or immediately frozen in liquid $\mathrm{N}_{2}$ and kept frozen until analysis. To refine the picture on how $\mathrm{Cd}$ and $\mathrm{Cu}$ interact for their respective uptake and distribution in plants, an additional and short-term experiment (3 days) was undertaken (in similar conditions) so as to minimize the influence of dilution/concentration effects associated with plant tissue growth, commonly observed in long-term experiments.

\section{Assessment of morphological changes and elements uptake}

After sampling, roots were desorbed by immersion with $20 \mathrm{mM}$ EDTA- $\mathrm{Na}_{2}$ for $3 \mathrm{~h}$ and then extensively washed in running deionized water for thorough metals elution (Zhou et al. 2007; Zeng et al. 2012). Then, plant samples (shoots and roots) were oven-dried at $105{ }^{\circ} \mathrm{C}$ for $3 \mathrm{~h}$, followed by $80^{\circ} \mathrm{C}$ for $48 \mathrm{~h}$, and weighed immediately after removal from the oven until biomass become stable (Momoh and Zhou 2001).

After dry biomass determination of plants, contents of $\mathrm{Cd}, \mathrm{Cu}$, and different mineral nutrients $(\mathrm{K}, \mathrm{Mg}, \mathrm{Ca}, \mathrm{Fe}, \mathrm{Zn}$, $\mathrm{Mn}$ ) in root and shoot tissues were measured. Dried samples were wet-digested in a mixture of concentrated $\mathrm{HNO}_{3}: \mathrm{HClO}_{4}(2: 1, \mathrm{v} / \mathrm{v})$, then heated at $80{ }^{\circ} \mathrm{C}$ in water bath for about $2 \mathrm{~h}$ (Gill et al. 2015), and elements contents were determined by inductively coupled plasma-optical emission spectrometry (ICP-OES, Optima 8000 DV, PerkinElmer, USA). Amounts of metal accumulated in plant tissues were obtained by multiplying the metal concentration by plant tissues dry weights.

\section{Photosynthetic pigments analysis}

Chlorophyll was extracted from upper second fully expanded leaves with $96 \%$ (v/v) ethanol, and the concentration was estimated according to Lichtenthaler and Wellburn (1983).

\section{Determination of indices of oxidative stress}

Oxidative damage to lipids (expressed as malondialdehyde content) and contents of reactive oxygen species (hydrogen peroxide and superoxide radical) were measured in roots and upper second fully expanded leaves. Samples $(0.5 \mathrm{~g})$ were extracted with $5 \mathrm{~mL}$ of $0.1 \%(\mathrm{w} / \mathrm{v})$ trichloroacetic acid (TCA), and homogenates were centrifuged at $12,000 \times g$ for $15 \mathrm{~min}$ at $4{ }^{\circ} \mathrm{C}$. The content of malondialdehyde (MDA) was estimated following the procedure of Heath and Packer (1968). A mixture made of $1 \mathrm{~mL}$ aliquot extract and $4 \mathrm{~mL} 0.5 \%$ thiobarbituric acid (TBA) in $20 \%$ TCA was incubated at $95{ }^{\circ} \mathrm{C}$ for $30 \mathrm{~min}$ and then quickly cooled in ice bath to terminate the reaction. The cooled mixture was centrifuged at $10,000 \times g$ for $10 \mathrm{~min}$, and the absorbance of supernatant was recorded at $532 \mathrm{~nm}$. Correction for non-specific absorption was made by subtracting values read at $600 \mathrm{~nm}$, and the level of MDA was calculated using extinction coefficient of $155 \mathrm{mM}^{-1} \mathrm{~cm}^{-1}$. Hydrogen peroxide $\left(\mathrm{H}_{2} \mathrm{O}_{2}\right)$ accumulation in leaves and roots was measured according to Velikova et al. (2004). In total $0.5 \mathrm{~mL}$ of $10 \mathrm{mM}$ potassium phosphate buffer $(\mathrm{pH}$ 7.0) and $1 \mathrm{~mL}$ of $1 \mathrm{M} \mathrm{KI}$ were added to $0.5 \mathrm{~mL}$ of the supernatant, and the absorbance of the mixture was read at $390 \mathrm{~nm}$. The $\mathrm{H}_{2} \mathrm{O}_{2}$ contents were estimated from a standard curve.

For measurement of superoxide radical $\left(\mathrm{O}_{2}^{--}\right)$, plant material $(0.5 \mathrm{~g})$ were homogenized in $3 \mathrm{~mL}$ of $65 \mathrm{mM}$ potassium phosphate buffer ( $\mathrm{pH} 7.8$ ) and extract was centrifuged at $5000 \times g$ for $10 \mathrm{~min}$ at $4{ }^{\circ} \mathrm{C}$ (Jiang and Zhang 2001). One milliliter of the supernatant was mixed with $0.9 \mathrm{~mL}$ of $65 \mathrm{mM}$ potassium phosphate buffer $(\mathrm{pH} 7.8)$ and $0.1 \mathrm{~mL}$ of $10 \mathrm{mM}$ hydroxylamine hydrochloride, and incubated at $25^{\circ} \mathrm{C}$ for $20 \mathrm{~min}$. To $1 \mathrm{~mL}$ of the incubated mixture, $1 \mathrm{~mL}$ of $17 \mathrm{mM}$ sulfanilamide and $1 \mathrm{~mL}$ of $7 \mathrm{mM}$ $\dot{\alpha}$-naphthylamine were added, followed by further $20 \mathrm{~min}$ incubation at $25{ }^{\circ} \mathrm{C}$. Next, $n$-butanol in the same volume $(3 \mathrm{~mL})$ was added and centrifuged at $1500 \times g$ for $5 \mathrm{~min}$. The absorbance in the aqueous solution was read at $530 \mathrm{~nm}$. A standard curve was utilized to calculate the rate of superoxide generation.

\section{Assessment of metals interactive effects on plant growth and physiological attributes}

Possible interaction between $\mathrm{Cd}$ and $\mathrm{Cu}$ were assessed using Abbott's model that presumes an independent action of mixture components and considers any deviation from this hypothesis as an indication of interaction between mixture components (Gisi 1996; Teisseire et al. 1999). Based on individual toxicities of $\mathrm{Cd}\left(T_{\mathrm{Cd}}\right)$ and $\mathrm{Cu}\left(T_{\mathrm{Cu}}\right)$ measured experimentally, Abbott's formula helped to predict the combined toxicity of $\mathrm{Cd}$ and $\mathrm{Cu}\left(T_{\text {pre }}\right)$ assuming an independent action of metals in mixture:

$T_{\text {pre }}=\left(T_{\mathrm{Cd}}+T_{\mathrm{Cu}}\right)-\frac{T_{\mathrm{Cd}} \times T_{\mathrm{Cu}}}{100}$ 
The ratio between the mixture toxicity experimentally observed $\left(T_{\mathrm{obs}}\right)$ and the mixture toxicity predicted by Abbott's formula ( $T_{\text {pre }}$ ) was calculated to check the existence of possible interaction between $\mathrm{Cd}$ and $\mathrm{Cu}: T_{\mathrm{obs}} / T_{\text {pre }}$ value $=1$ indicated additivity of metals toxicity, while value $>1$ and $<1$ denoted synergism and antagonism, respectively.

\section{Statistical analysis}

The experiment was carried out through a completely randomized design, and the analysis of variance (ANOVA) was carried out for statistically significant differences using the statistical package SPSS, version 16.0 (SPSS, Chicago, IL, USA). The results are the mean \pm SD of at least three independent replicates, and the mean differences were compared utilizing the Duncan's multiple range test.

\section{Results and discussion}

\section{$\mathrm{Cd}$ and $\mathrm{Cu}$ uptake and distribution in plants}

Cadmium $(\mathrm{Cd})$ and copper $(\mathrm{Cu})$ contents in 3 and 15 days metal-treated plants are illustrated in figures (Figs. 1, 2). Concentrations of both metals in roots and shoots increased with elevation of metals exposure strength. However, $\mathrm{Cu}$ presented relatively low mobility, with 2- to 3- and 4- to fivefold lower contents than $\mathrm{Cd}$, respectively, in root and shoot tissues. Likewise, its root-to-shoot translocation rate was twofold lower (Fig. 3), which was thought to be in relation to its higher exchange capacity than Cd (Gondar et al. 2006). Previously, Nishizono et al. (1987) also observed a higher retention of $\mathrm{Cu}$ at root cell wall of Athyrium yokoscense compared to $\mathrm{Cd}$. Zhou et al. (2007) also demonstrated that $\mathrm{Cu}$ adsorption in maize root cell wall was such tight that a large amount of metal ions were retained in the root apoplast. Despite their varied level of accumulation in B. napus plants, both $\mathrm{Cd}$ and $\mathrm{Cu}$ mainly accumulated in root $(\mathrm{TF}<100)$. Generally, plant ability to reduce the intracellular concentrations of metals particularly in the aboveground part, is assumed to be a tolerance trait for non-hyperaccumulator plants (Lin and Aarts 2012). Correspondingly, more tolerant genotypes are expected to accumulate fewer amounts of metal, like also demonstrated by a number of studies (Guo et al. 2004, 2007; Ali et al. 2011; Islam et al. 2015). In the current study, however, almost equivalent amounts of metals were observed in roots and shoots of Zheda 622 and ZS 758, two cultivars differing in metal tolerance (Figs. 1 and 2). These results corroborated the view that tolerant genotypes are not invariably low in metals contents (Kuboi et al. 1987; Wu and Zhang 2002; Belimov et al. 2003).
Simultaneous supply of $\mathrm{Cd}$ and $\mathrm{Cu}$ to the medium affected each other's uptake and accumulation in B. napus plants, suggesting their interactive relationship at root surface (Figs. 1, 2). In both cultivars, the presence of $\mathrm{Cu}$ decreased the tissues concentrations of $\mathrm{Cd}$, whereas $\mathrm{Cd}$ induced an opposite effect (increase) on $\mathrm{Cu}$ contents. To ascertain whether the observed effects were associated with changes in metal uptake rate rather than a consequence of growth dilution/concentration effects, we examined the extent of metals accumulation in the shoots (Fig. 1c) and roots (Fig. 2c) of 15-day-treated plants that presented obvious signs of growth inhibition. Obtained results confirmed both the $\mathrm{Cu}$ inhibitory effects and the $\mathrm{Cd}$ stimulatory effects on each other's uptake, echoing the pattern recorded in the short-term experiment (Figs. 1a, 2a). It was apparent that $\mathrm{Cd}$ and $\mathrm{Cu}$ affected each other's uptake through distinct mechanisms, considering the contrast in their reciprocal effects. Normally, uptake of $\mathrm{Cu}$ occurred as monovalent form through specific transporters (COPTs) (Andres-Colas et al. 2010), although a marginal amount of $\mathrm{Cu}^{2+}$ could also be taken up through ZIP transporters (Cuypers et al. 2012). Consequently, reduction of $\mathrm{Cu}^{2+}$ to $\mathrm{Cu}^{+}$(mediated by ferric reductase) is considered as a prerequisite for $\mathrm{Cu}$ uptake by plants (Burkhead et al. 2009). Therefore, the $\mathrm{Cd}$ stimulatory effects on $\mathrm{Cu}$ uptake could be explained by an improved activity of ferric reductase (FRO) with the presence of $\mathrm{Cd}$ ions that might enhance the pool of $\mathrm{Cu}^{+}$in the rooting medium and its subsequent uptake by plants. Ghasemi et al. (2009) also observed that $\mathrm{Ni}$ exposure enhanced the activity of $\mathrm{Cu}^{2+}$ reductase at plant root surface, which was presumed to increase $\mathrm{Cu}$ accumulation in Alyssum inflatum. Likewise, Zhou et al. (2007) indicated a close relationship between the extent of $\mathrm{Cu}$ uptake by maize seedlings and the potential of cysteine to change the oxidation state of $\mathrm{Cu}$ in the rhizosphere. The $\mathrm{Cd}$ enhancing effects on copper uptake was also reported in barley (Lachman et al. 2004) and Chlorella vulgaris (Franklin et al. 2002; Qian et al. 2009). In contrast to these reports, Huang et al. (2009) did not notice any Cd stimulatory effect on $\mathrm{Cu}$ accumulation in rice. Besides $\mathrm{Cd}$, the presence of $\mathrm{Pb}$ was also observed to increase $\mathrm{Cu}$ accumulation in Cucumis sativus (An et al. 2004). Converse to $\mathrm{Cd}$ effect, $\mathrm{Cu}$ restricted the accumulation of $\mathrm{Cd}$ in B. napus (Figs. 1, 2), which is arguably in relation to metal competition for binding sites at plant root surface (Gondar et al. 2006).

Current results delineated that the extent of $\mathrm{Cd}$ and $\mathrm{Cu}$ interaction varied with respect to level of metals concentration in the growth medium. Surprisingly, Cd stimulated the uptake of $\mathrm{Cu}$ only at lower concentration $(50 \mu \mathrm{M})$ (Figs. 1, 2), which appeared to be indicative of limited influence of $\mathrm{Cd}$ on biological processes related to $\mathrm{Cu}$ accumulation in B. napus. On the contrary, the magnitude 

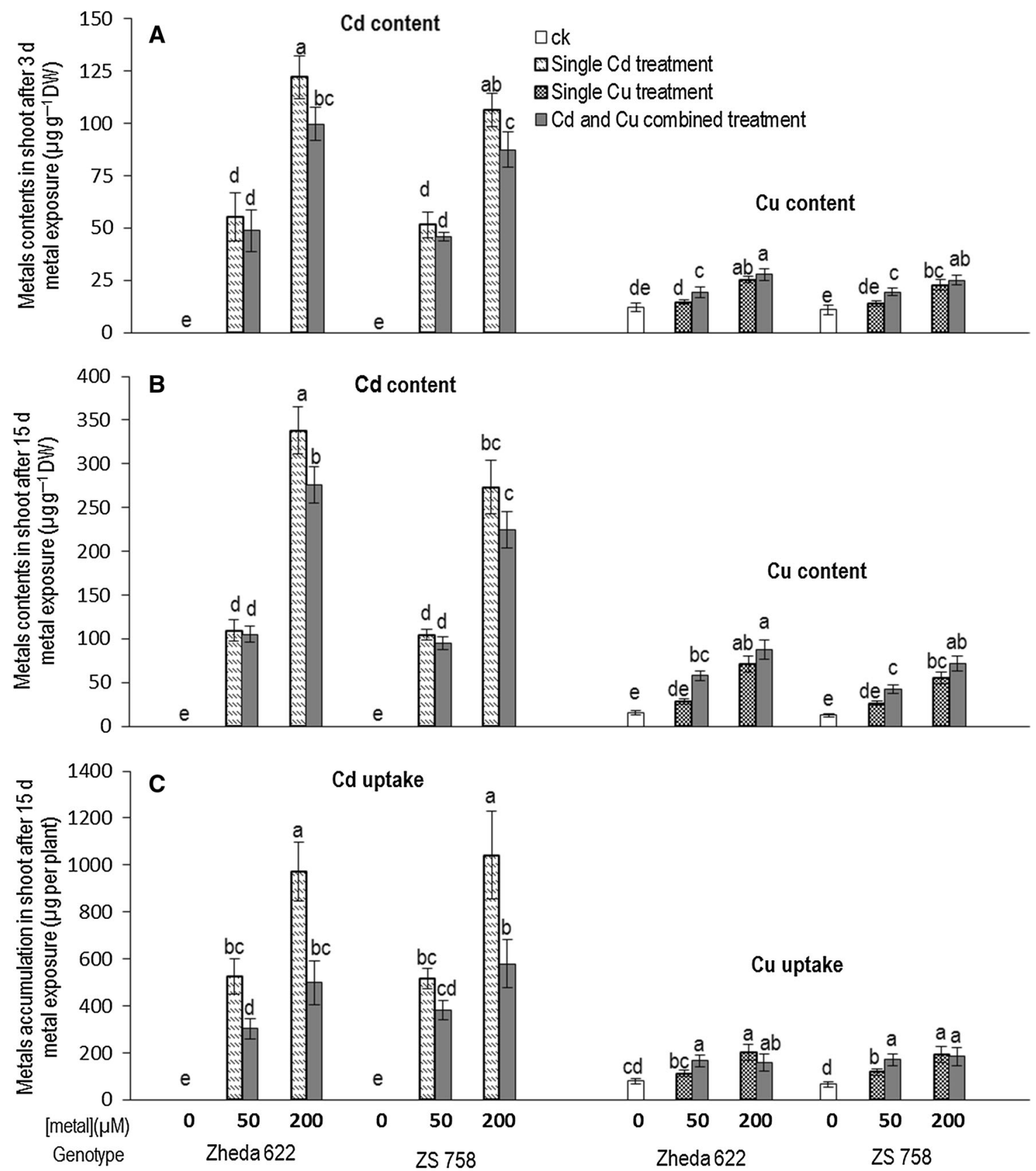

Fig. 1 Cadmium and copper contents in the shoots of Brassica napus plants exposed to a 3-day and b 15-day metal treatments $(\mu \mathrm{M})$; and the amount of metals $(\mathrm{Cd}$ and $\mathrm{Cu})$ accumulation in $\mathbf{c} 15$-day-treated plants. Bars represent SD of means from at least three independent

replicates. Means followed by same letters for the same type of metal are not significantly different by Duncan's multiple range test $(P<0.05)$

of $\mathrm{Cu}$ action (on $\mathrm{Cd}$ uptake) increased with metal exposure strength (Figs. 1, 2), suggesting that the more the metals were present in the rooting medium, the more $\mathrm{Cd}$ was outcompeted by $\mathrm{Cu}$ for binding to root surface.

In both cultivars and at either level of metals concentrations, the presence of one metal did not affect the rootto-shoot translocation rate of the other (Fig. 3). Hence, it was thought that $\mathrm{Cd}$ and $\mathrm{Cu}$ scarcely interacted within plant.

\section{Plant growth, chlorophyll accumulation,} and oxidative stress

Single and combined effects of excess $\mathrm{Cd}$ and $\mathrm{Cu}$, measured in terms of plant biomass reduction and decrease in chlorophyll content, are presented in Fig. 4, respectively,and their effects on ROS accumulation $\left(\mathrm{O}_{2}^{--}\right.$and $\left.\mathrm{H}_{2} \mathrm{O}_{2}\right)$ and MDA contents are shown in Fig. 5a-f. Fifteen-day exposure of plants to $\mathrm{Cd}$ and $\mathrm{Cu}$ toxicity provoked a dose-responsive reduction in shoot and 

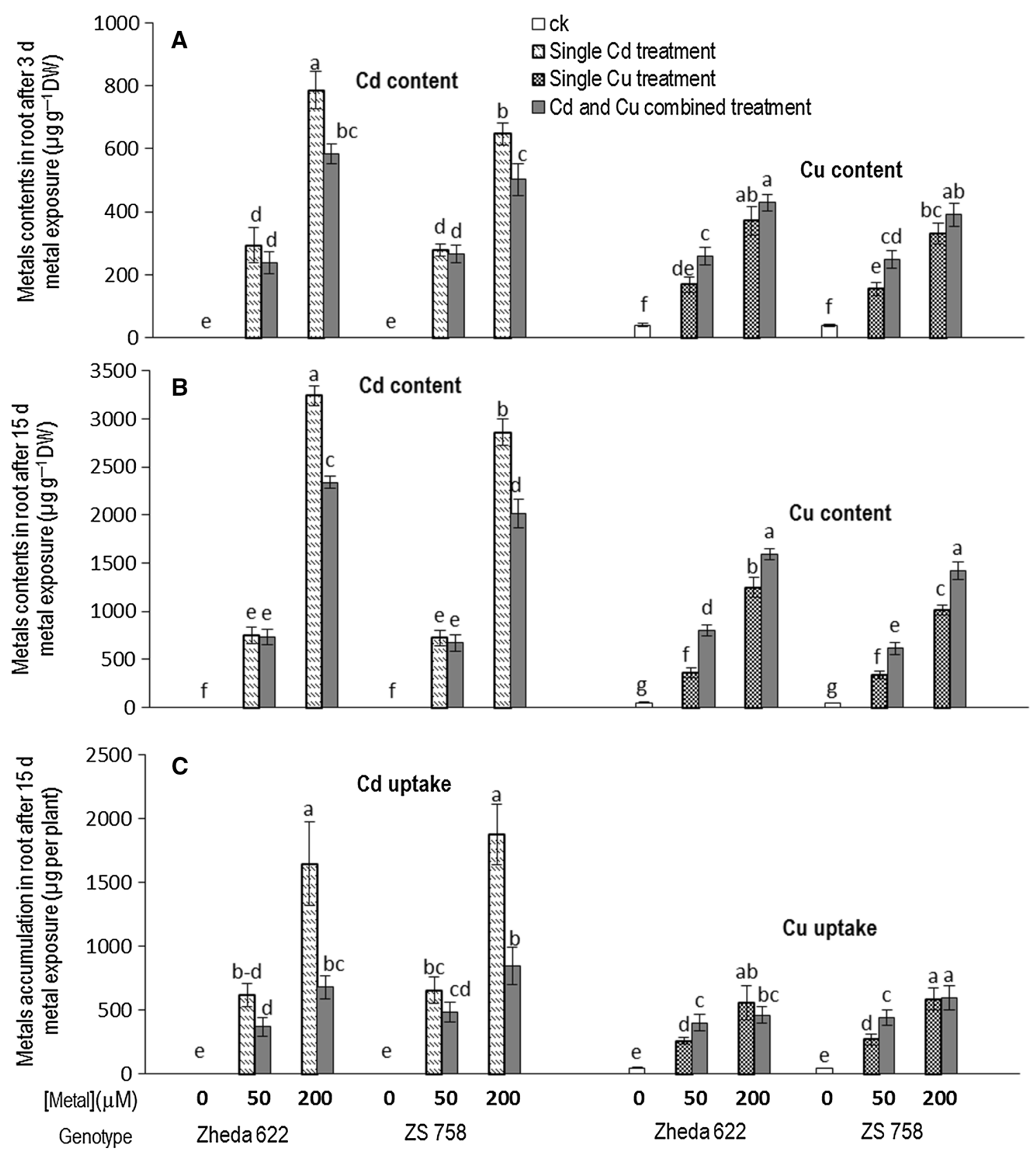

Fig. 2 Cadmium and copper contents in the roots of Brassica napus plants exposed to a 3-day and b 15-day metal treatments $(\mu \mathrm{M})$; and amount of metals $(\mathrm{Cd}$ and $\mathrm{Cu})$ accumulation in c 15-day-treated plants. Bars represent standard deviation of means from at least three

root dry biomass and chlorophyll contents relative to controls. Similarly, both $\mathrm{Cd}$ and $\mathrm{Cu}$ treatments induced significant accumulation of ROS and MDA in plants tissues, which are recurrent manifestations of metals phytotoxicity (Gill and Tuteja 2010). However, the extent of toxicity was not consistent with the level of metals bioaccumulation, as $\mathrm{Cu}$ caused more deleterious effects despite its moderate bioaccumulation compared to Cd, notably at lower level of metals concentrations $(50 \mu \mathrm{M})$. This was believed to be in connection with the differential chemical properties between the two metals. In independent replicates. Means followed by same letters for the same type of metal are not significantly different by Duncan's multiple range test $(P<0.05)$

fact, due to its redox properties, $\mathrm{Cu}$ is prone to directly generate ROS through Fenton-Haber-Weiss reaction (Yadav 2010) and is considered as one of the most powerful catalysts of free radical formation (Ravet and Pilon 2013). Conversely, $\mathrm{Cd}$ is a non-redox active metal that can generate ROS indirectly by interaction with antioxidant molecules (Valko et al. 2005) or by disruption the electron transport chain (Andresen and Küpper 2013). Nonetheless, Cd toxicity appeared to increase faster with elevation of metals concentrations from 50 to $200 \mu \mathrm{M}$, producing an equistrength inhibition of plant 

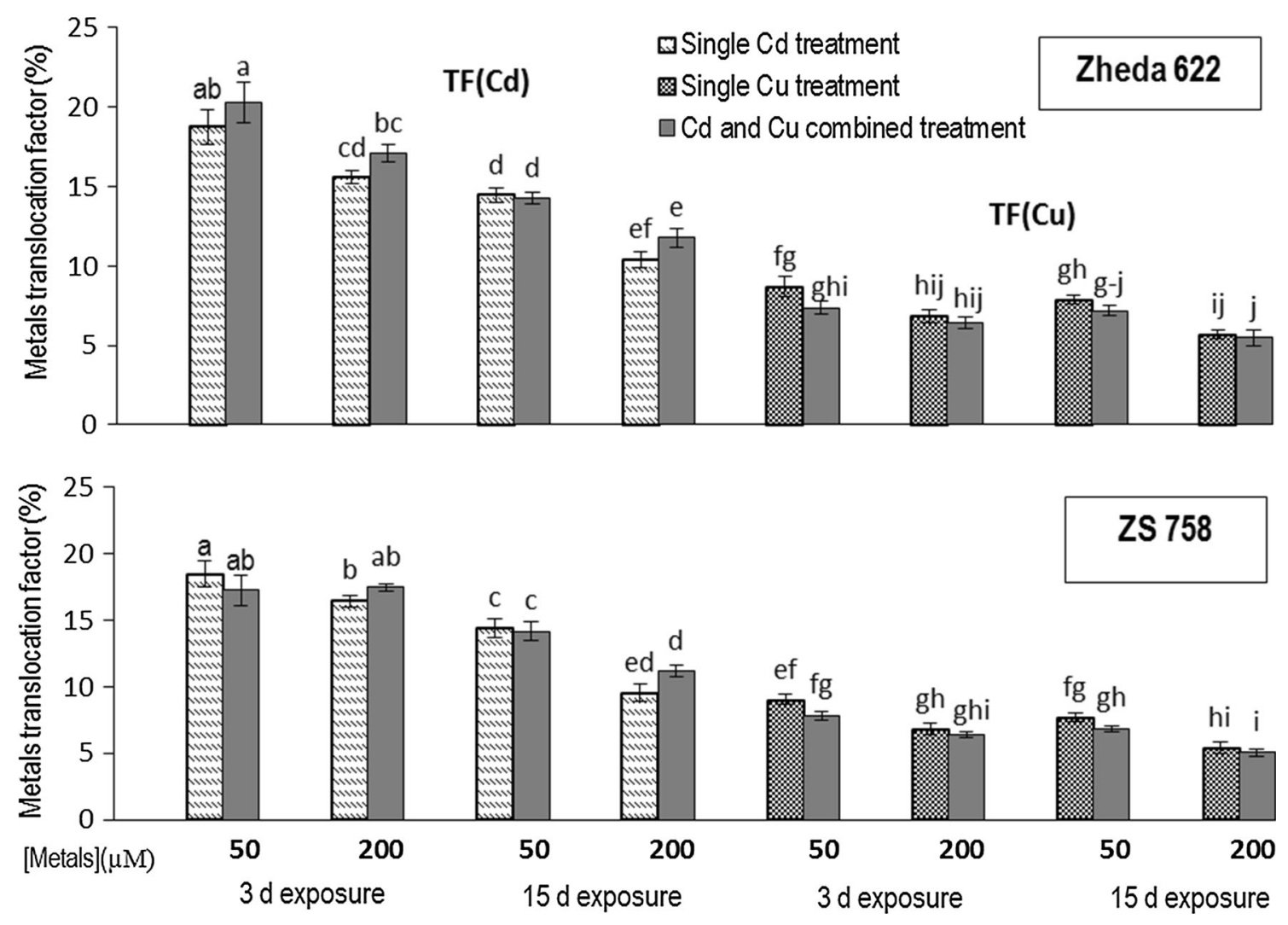

Fig. 3 Root-to-shoot translocation factors of $\mathrm{Cd}$ and $\mathrm{Cu}$ in 3 and 15 days Brassica napus plants exposure to different concentrations (50 and $200 \mu \mathrm{M}$ ) of both cadmium and copper. Bars represent

growth (Fig. 4a, b) and an equivalent oxidative stress compared to Cu effects (Fig. 5e,f). The toxic effects of both metals varied with respect to cultivars, and as naturally expected, much stunted plant growth (Fig. 4a, b), greater chlorophyll loss (Fig. 4c), and higher oxidative damages (Fig. 5) were observed in the sensitive cultivar Zheda 622 than cultivar ZS 758 (tolerant), confirming the earlier reported genotypic difference in metals tolerance between the two cultivars (Farooq et al. 2015; Gill et al. 2015).

Combined effects of $\mathrm{Cd}$ and $\mathrm{Cu}$ caused further plant growth inhibition, chlorophyll loss and oxidative stress compared to alone $\mathrm{Cd}$ and $\mathrm{Cu}$ stress. Importantly, as revealed by Abbott's model, the resulting mixture toxicity was different from the individual metal effects (Tables 1, 2). Synergistic effects (more than additive effects) were noted at low metal concentrations, while converse effects (antagonistic) occurred at higher level of metals exposure, denoting varied toxicity responses of $B$. napus plants with respect to the level of metal exposure. The extent of metal toxicity is generally associated with the amount of metals likely to accumulate in plant tissues (Davis and Becker 1978). In the present study, $\mathrm{Cu}$ and $\mathrm{Cu}$ synergistic effects on plant growth, chlorophyll content and oxidative stress were recorded only in conditions where the $\mathrm{Cu}$ uptake was standard deviation of means from at least three independent replicates. Means followed by same letters are not significantly different by Duncan's multiple range test $(P<0.05)$

effectively stimulated by the presence of $\mathrm{Cd}$ (at low metals concentrations). Likewise, their antagonistic effects at high metals concentrations could be ascribed to the reduced $\mathrm{Cd}$ effect on $\mathrm{Cu}$ bioaccumulation, coupled with the $\mathrm{Cu}$-restricting effect on Cd uptake (Figs. 1, 2). Different from current results, Qian et al. (2009) found no direct relationship between the $\mathrm{Cd}$-led $\mathrm{Cu}$ uptake and the algal $(C$. vulgaris) growth responses; which is most probably due to differences in metals concentrations used. Synergism is the interaction of most concern from toxicological point of view, since it increases the overall toxicity of chemicals mixture (Teisseire et al. 1999). Correspondingly, the Cdled $\mathrm{Cu}$ bioaccumulation observed in this study, which is assumed to drive metals synergistic toxicity to $B$. napus plants, constitutes a matter of toxicological significance, for which underlying molecular basis and relevant environmental factors need to be clarified. $\mathrm{Cd}$ and $\mathrm{Cu}$ synergistic effects on plant growth inhibition, chlorophyll loss and oxidative stress were observed in both cultivars Zheda 622 and ZS 758, but a stronger extent changes were noted in the sensitive cultivar Zheda 622. Previously, significant genotypic differences have been detected between cultivars ZS 758 and Zheda 622 regarding their ability to modulate the intracellular activity of metals ions (data not shown); 

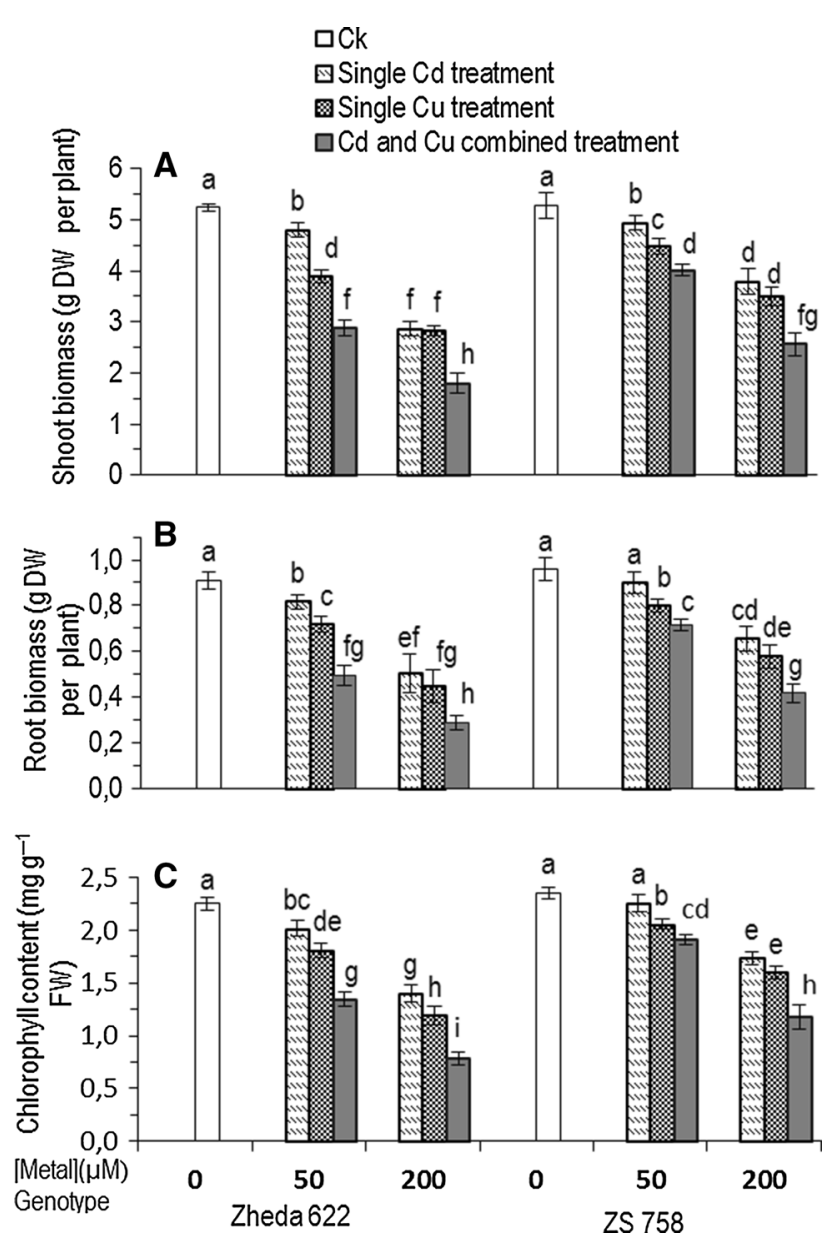

Fig. 4 Effects of different concentrations (50 and $200 \mu \mathrm{M})$ of both cadmium and copper on a, b shoot and root dry weight and c chlorophyll contents in 15-day-treated Brassica napus plants. Bars represent standard deviation of means from at least three independent replicates. Means followed by same letters are not significantly different by Duncan's multiple range test $(P<0.05)$

this could be a possible reason accounting for the greater synergistic effects noted in the sensitive cultivar Zheda 622, which presented a lesser growth. Guo et al. (2007) also detected an important synergistic effect of $\mathrm{Al}, \mathrm{Cd}$, and $\mathrm{Cu}$ in a sensitive cultivar of barley, which was not noticed with the tolerant cultivar. However, both individual and combined treatments of $\mathrm{Cd}$ and $\mathrm{Cu}$ significantly affected plant growth, chlorophyll accumulation and oxidative stress, although in some cases, the low level of $\mathrm{Cd}$ treatment did not induce significant effects.

\section{Nutrients contents}

Effects of different concentrations of both $\mathrm{Cd}$ and $\mathrm{Cu}$ on nutrients contents in the leaves of 15-day-treated B. napus plants have been shown in Table 3. Addition of Cd or $\mathrm{Cu}$ to the growth medium affected the mineral composition in a similar fashion. Both metals decreased the content of $\mathrm{K}, \mathrm{Fe}, \mathrm{Zn}$, and
$\mathrm{Mn}$ in a dose-responsive trend in the two cultivars (Zheda 622 and ZS 758), but no significant effects were detected on $\mathrm{Ca}$ and $\mathrm{Mg}$ contents. $\mathrm{Cu}$ induced significant reductions of $\mathrm{K}, \mathrm{Fe}, \mathrm{Zn}$ and $\mathrm{Mn}$ contents at either level of concentration, while the deleterious effects of $\mathrm{Cd}$ were mostly noticeable at higher concentration, except for $\mathrm{Zn}$ contents (Table 3). It was evident that $\mathrm{Cu}$ stress was much more critical for $\mathrm{K}$ and $\mathrm{Mn}$ nutrition than $\mathrm{Cd}$ stress; conversely, $\mathrm{Cd}$ stress showed more deleterious effects on $\mathrm{Zn}$ content in comparison with $\mathrm{Cu}$. A number of reports also suggested a strong reduction of $\mathrm{Mn}$ uptake as a common manifestation of $\mathrm{Cu}$ phytotoxicity (Lidon and Henriques 1992; Lin and Wu 1994), which is not necessarily the case for Cd (Kabata-Pendias, 2011); likewise, Cd similarity with $\mathrm{Zn}$ is considered as a recurrent cause of its phytotoxicity (Verbruggen et al. 2009). Combined effects of metals on plant mineral nutrition have received little attention from researchers. Changes in mineral composition have been investigated under combined stresses of $\mathrm{Al}$ and $\mathrm{Cd}$ in barley (Guo et al. 2004), Al and Cr in barley (Ali et al. 2011), As and Cr in jute (Islam et al. 2015), and observed results have shown a further decrease in nutrient content compared to effects of single metal. Similarly, current results indicated that $\mathrm{Cd}$ and $\mathrm{Cu}$ stress together caused marked reduction in nutrients relative to control. However, when compared to $\mathrm{Cd}$ and $\mathrm{Cu}$ stress alone, the overall effects were not overly exacerbated in mixture treatments (Table 3), and contrary to combined effects of metals on plant growth and oxidative stress, additivity (on Fe and $\mathrm{Zn}$ contents) and antagonism (on $\mathrm{K}$ and $\mathrm{Mn}$ contents) best described the interactive effects of $\mathrm{Cd}$ and $\mathrm{Cu}$ on mineral composition in B. napus plants (Table 4). Similar to their single effects, the combined effects of $\mathrm{Cd}$ and $\mathrm{Cu}$ did not affect $\mathrm{Ca}$ and $\mathrm{Mg}$ uptake (Table 4). Both levels of $\mathrm{Cu}$ and $\mathrm{Cd}$ treatments, individually and in combination significantly reduced $\mathrm{K}, \mathrm{Fe}$ and $\mathrm{Zn}$ contents, but no effects were detected on $\mathrm{Ca}$ and $\mathrm{Mg}$ nutrition. Mn contents were significantly affected only at high concentration of $\mathrm{Cd}$, while a significant reduction was recorded at either level of $\mathrm{Cu}$ concentration.

Although both single and combined stresses of $\mathrm{Cd}$ and $\mathrm{Cu}$ significantly altered mineral composition in plants, the reduction extent did not differ between the sensitive cultivar (Zheda 622) and the tolerant cultivar (ZS 758) relative to their respective controls (Table 3). Hence it may be assumed that reduction in nutrients contents was less accounted for the greater sensitivity of Zheda 622 to $\mathrm{Cd}$ and $\mathrm{Cu}$ stresses than $\mathrm{ZS} 758$.

\section{Conclusion}

The findings of present study revealed an interactive but contrasting relationship between $\mathrm{Cd}$ and $\mathrm{Cu}$ for their uptake and accumulation in B. napus plants; $\mathrm{Cd}$ enhanced $\mathrm{Cu}$ bioaccumulation while its own uptake was restricted by 


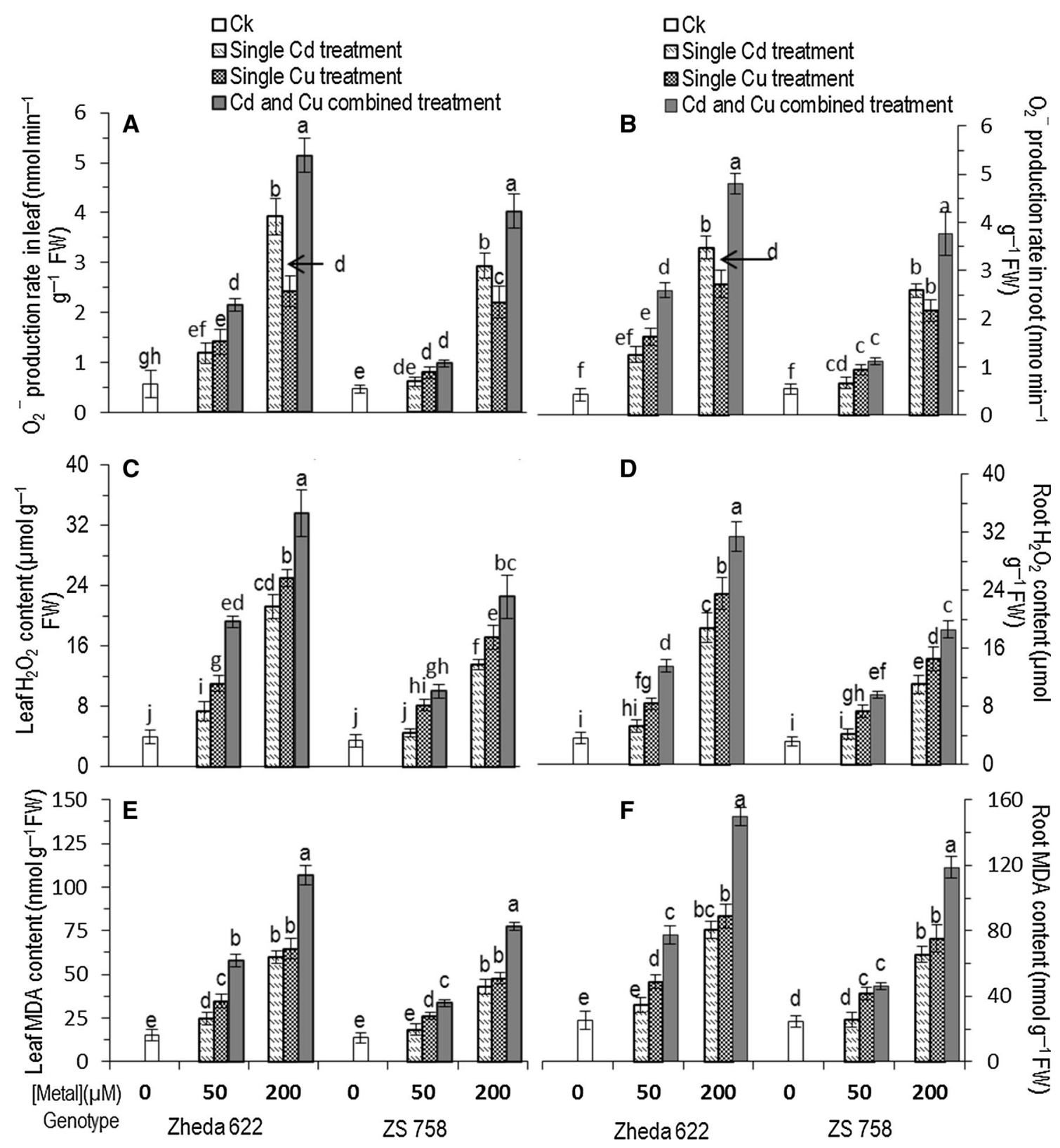

Fig. 5 Effects of different concentrations $(0,50$ and $200 \mu \mathrm{M})$ of both cadmium and copper on the levels of $(\mathbf{a}, \mathbf{b}) \mathrm{O}_{2}^{-},(\mathbf{c}, \mathbf{d}) \mathrm{H}_{2} \mathrm{O}_{2}$ and MDA (e, f) in leaves and root of 15-day-treated Brassica napus. Bars

represent standard deviation of means from at least three independent replicates. Means followed by same letters are not significantly different by Duncan's multiple range test $(P<0.05)$
Table 1 Interactive effects of cadmium and copper on biomass accumulation and chlorophyll content in 15 days treated in two Brassica napus cultivars

\begin{tabular}{lllll}
\hline Treatment & Cultivar & \multicolumn{4}{l}{ Toxicity ratio $\left(T_{\text {obs }} / T_{\text {pre }}\right)^{\mathrm{a}}$} \\
\cline { 3 - 5 } & & Shoot DW & Root DW & Chlorophyll \\
\hline $50 \mu \mathrm{M} \mathrm{Cd}+50 \mu \mathrm{M} \mathrm{Cu}$ & Zheda 622 & $1.33 \pm 0.09 \mathrm{a}$ & $1.44 \pm 0.16 \mathrm{a}$ & $1.35 \pm 0.11 \mathrm{a}$ \\
& ZS 758 & $1.12 \pm 0.09 \mathrm{~b}$ & $1.13 \pm 0.12 \mathrm{~b}$ & $1.11 \pm 0.12 \mathrm{~b}$ \\
$200 \mu \mathrm{M} \mathrm{Cd}+200 \mu \mathrm{M} \mathrm{Cu}$ & Zheda 622 & $0.73 \pm 0.04 \mathrm{c}$ & $0.72 \pm 0.03 \mathrm{c}$ & $0.77 \pm 0.03 \mathrm{c}$ \\
& ZS 758 & $0.84 \pm 0.07 \mathrm{c}$ & $0.79 \pm 0.06 \mathrm{c}$ & $0.86 \pm 0.09 \mathrm{c}$ \\
\hline
\end{tabular}

Data are mean \pm SD of at least three independent replicates. Values within column followed by the same letter are not significantly different by Duncan's multiple range test $(P<0.05)$

a Toxic effects of metals mixture were measured experimentally $\left(T_{\text {obs }}\right)$ and were predicted with Abbot's model $\left(T_{\text {pre }}\right) . T_{\text {obs }} / T_{\text {pre }}$ value $=1$ indicated additivity of $\mathrm{Cd}$ and $\mathrm{Cu}$ individual effects, value $>1$ synergism and value $<1$ antagonism 
Table 2 Interactive effects of cadmium and copper on ROS $\left(\mathrm{O}_{2}^{--}\right.$and $\left.\mathrm{H}_{2} \mathrm{O}_{2}\right)$ and MDA accumulation in leaf and root of two cultivars of Brassica napus

\begin{tabular}{|c|c|c|c|c|c|c|c|}
\hline \multirow[t]{3}{*}{ Treatment } & \multirow[t]{3}{*}{ Cultivar } & \multicolumn{6}{|c|}{ Toxicity ratio $\left(T_{\mathrm{obs}} / T_{\mathrm{pre}}\right)^{\mathrm{a}}$} \\
\hline & & \multicolumn{2}{|l|}{$\mathrm{O}_{2}^{--}$} & \multicolumn{2}{|l|}{$\mathrm{H}_{2} \mathrm{O}_{2}$} & \multicolumn{2}{|l|}{ MDA } \\
\hline & & Leaf & Root & Leaf & Root & Leaf & Root \\
\hline \multirow{2}{*}{$50 \mu \mathrm{M} \mathrm{Cd}+50 \mu \mathrm{M} \mathrm{Cu}$} & Zheda 622 & $1.09 \pm 0.09 \mathrm{ab}$ & $1.06 \pm 0.08 \mathrm{a}$ & $1.42 \pm 0.07 \mathrm{a}$ & $1.53 \pm 0.13 \mathrm{a}$ & $1.36 \pm 0.12 \mathrm{a}$ & $1.52 \pm 0.16 \mathrm{a}$ \\
\hline & ZS 758 & $1.10 \pm 0.13 \mathrm{a}$ & $1.11 \pm 0.12 \mathrm{a}$ & $1.14 \pm 0.16 \mathrm{a}$ & $1.25 \pm 0.09 b$ & $1.10 \pm 0.10 \mathrm{~b}$ & $1.19 \pm 0.11 b$ \\
\hline \multirow[t]{2}{*}{$200 \mu \mathrm{M} \mathrm{Cd}+200 \mu \mathrm{M} \mathrm{Cu}$} & Zheda 622 & $0.87 \pm 0.06 \mathrm{ab}$ & $0.81 \pm 0.04 \mathrm{~b}$ & $0.71 \pm 0.08 b$ & $0.73 \pm 0.05 c$ & $0.79 \pm 0.05 c$ & $0.81 \pm 0.04 \mathrm{c}$ \\
\hline & ZS 758 & $0.84 \pm 0.08 b$ & $0.87 \pm 0.12 \mathrm{ab}$ & $0.76 \pm 0.11 b$ & $0.77 \pm 0.06 \mathrm{c}$ & $0.87 \pm 0.03 \mathrm{c}$ & $0.84 \pm 0.06 \mathrm{c}$ \\
\hline
\end{tabular}

Data are mean \pm SD of at least three independent replicates. Values within column followed by the same letter are not significantly different by Duncan's multiple range test $(P<0.05)$

${ }^{\text {a }}$ Toxic effects of metals mixture were measured experimentally $\left(T_{\text {obs }}\right)$ and were predicted with Abbot's model $\left(T_{\text {pre }}\right) . T_{\text {obs }} / T_{\text {pre }}$ value $=1$ indicated additivity of $\mathrm{Cd}$ and $\mathrm{Cu}$ individual effects, value $>1$ synergism and value $<1$ antagonism

Table 3 Effects of different concentrations of both cadmium and copper on the uptake of mineral nutrients in the leaves of two cultivars of Brassica napus

\begin{tabular}{|c|c|c|c|c|c|c|}
\hline Treatment & $\begin{array}{l}\mathrm{K} \\
\left(\mathrm{mg} \mathrm{g}^{-1} \mathrm{DW}\right)\end{array}$ & $\mathrm{Ca}$ & $\mathrm{Mg}$ & $\begin{array}{l}\mathrm{Fe} \\
\left(\mu \mathrm{g} \mathrm{g}^{-1} \mathrm{DW}\right)\end{array}$ & $\mathrm{Zn}$ & $\mathrm{Mn}$ \\
\hline \multicolumn{7}{|l|}{ Zheda 622} \\
\hline \multicolumn{7}{|l|}{$0 \mu \mathrm{M}$} \\
\hline $\mathrm{Ck}$ & $80.6 \pm 2.7 \mathrm{a}$ & $27.3 \pm 1.8 \mathrm{a}$ & $7.38 \pm 0.48 a$ & $352.0 \pm 20.7 a$ & $142.5 \pm 13.4 \mathrm{a}$ & $35.6 \pm 3.2 \mathrm{a}$ \\
\hline \multicolumn{7}{|l|}{$50 \mu \mathrm{M}$} \\
\hline $\mathrm{Cd}$ & $67.4 \pm 4.6 b$ & $27.3 \pm 2.4 \mathrm{a}$ & $7.41 \pm 0.54 \mathrm{a}$ & $332.3 \pm 16.5 a$ & $114.1 \pm 8.3 b c$ & $31.3 \pm 2.6 \mathrm{ab}$ \\
\hline $\mathrm{Cu}$ & $64.3 \pm 5.0 \mathrm{~b}$ & $26.3 \pm 0.9 \mathrm{a}$ & $7.10 \pm 0.11 \mathrm{a}$ & $263.7 \pm 25.1 b$ & $127.0 \pm 5.8 b$ & $21.6 \pm 2.0 \mathrm{c}$ \\
\hline $\mathrm{Cd}+\mathrm{Cu}$ & $59.5 \pm 4.1 b$ & $25.1 \pm 1.6 \mathrm{a}$ & $6.82 \pm 0.41 \mathrm{a}$ & $262.3 \pm 11.7 b$ & $106.2 \pm 6.0 \mathrm{c}$ & $21.9 \pm 2.9 \mathrm{c}$ \\
\hline \multicolumn{7}{|l|}{$200 \mu \mathrm{M}$} \\
\hline $\mathrm{Cd}$ & $64.1 \pm 3.4 b$ & $25.0 \pm 1.6 \mathrm{a}$ & $6.94 \pm 0.50 \mathrm{a}$ & $259.7 \pm 18.0 \mathrm{~b}$ & $97.5 \pm 7.4 \mathrm{~d}$ & $28.8 \pm 2.1 b$ \\
\hline $\mathrm{Cu}$ & $53.5 \pm 5.4 c$ & $24.3 \pm 1.8 \mathrm{a}$ & $6.76 \pm 0.26 a$ & $247.0 \pm 18.5 b$ & $112.2 \pm 7.8 \mathrm{bc}$ & $21.5 \pm 2.7 \mathrm{c}$ \\
\hline $\mathrm{Cd}+\mathrm{Cu}$ & $52.1 \pm 4.7 \mathrm{c}$ & $24.1 \pm 1.5 \mathrm{a}$ & $6.93 \pm 0.40 \mathrm{a}$ & $249.0 \pm 17.6 b$ & $86.9 \pm 6.8 \mathrm{~d}$ & $21.4 \pm 3.7 \mathrm{c}$ \\
\hline \multicolumn{7}{|l|}{ ZS 758} \\
\hline \multicolumn{7}{|l|}{$0 \mu \mathrm{M}$} \\
\hline $\mathrm{Ck}$ & $73.5 \pm 3.3 \mathrm{a}$ & $27.1 \pm 2.0 \mathrm{a}$ & $7.42 \pm 0.90 \mathrm{a}$ & $336.3 \pm 17.4 \mathrm{a}$ & $151.4 \pm 9.7 \mathrm{a}$ & $34.4 \pm 3.4 \mathrm{a}$ \\
\hline \multicolumn{7}{|l|}{$50 \mu \mathrm{M}$} \\
\hline $\mathrm{Cd}$ & $70.6 \pm 3.3 \mathrm{ab}$ & $27.1 \pm 2.3 \mathrm{a}$ & $7.27 \pm 0.58 \mathrm{a}$ & $311.0 \pm 14.5 b$ & $132.1 \pm 7.2 b$ & $29.9 \pm 3.2 \mathrm{a}$ \\
\hline $\mathrm{Cu}$ & $64.3 \pm 4.1 b c$ & $24.9 \pm 1.7 \mathrm{a}$ & $7.22 \pm 0.04 a$ & $307.7 \pm 8.5 b$ & $133.5 \pm 6.5 b$ & $19.8 \pm 2.3 \mathrm{c}$ \\
\hline $\mathrm{Cd}+\mathrm{Cu}$ & $63.8 \pm 2.7 \mathrm{c}$ & $26.1 \pm 1.3 \mathrm{a}$ & $6.98 \pm 0.33 \mathrm{a}$ & $284.3 \pm 6.7 \mathrm{c}$ & $117.5 \pm 5.5 \mathrm{c}$ & $21.1 \pm 2.7 \mathrm{c}$ \\
\hline \multicolumn{7}{|l|}{$200 \mu \mathrm{M}$} \\
\hline $\mathrm{Cd}$ & $67.1 \pm 2.4 \mathrm{bc}$ & $23.2 \pm 2.4 \mathrm{a}$ & $6.93 \pm 0.58 \mathrm{a}$ & $271.7 \pm 8.7 \mathrm{~cd}$ & $95.1 \pm 6.0 \mathrm{~d}$ & $26.8 \pm 3.3 b$ \\
\hline $\mathrm{Cu}$ & $55.6 \pm 4.1 d$ & $23.1 \pm 2.5 a$ & $6.86 \pm 0.56 a$ & $258.0 \pm 7.6 \mathrm{~d}$ & $118.3 \pm 5.6 \mathrm{c}$ & $19.2 \pm 2.6 \mathrm{c}$ \\
\hline $\mathrm{Cd}+\mathrm{Cu}$ & $55.3 \pm 2.8 \mathrm{~d}$ & $22.8 \pm 2.4 a$ & $6.60 \pm 0.69 a$ & $250.3 \pm 7.0 \mathrm{~d}$ & $97.8 \pm 5.5 \mathrm{~d}$ & $19.1 \pm 3.3 \mathrm{c}$ \\
\hline
\end{tabular}

Data are mean \pm SD of at least three independent replicates. Different letters within column for the same cultivar indicate significant differences by Duncan's multiple range test $(P<0.05)$

the presence of $\mathrm{Cu}$ in the medium. Consequently, their mixture toxicity gave rise to effects different from additively. However, synergistic effect was observed only at low metal concentrations, where $\mathrm{Cd}$ effectively induced $\mathrm{Cu}$ bioaccumulation. This demonstrates the ecotoxicological significance of the $\mathrm{Cd}$-led $\mathrm{Cu}$ uptake in B. napus and highlights the interest to clarify the molecular basis underlying this phenomenon. While the reduction extent of nutrients uptake was similar between cultivars, much stunted plant growth and oxidative stress were recorded with Zheda 622 as compared to ZS 758, confirming their varied level of tolerance to metal toxicity. Moreover, a 
Table 4 Interactive effects of cadmium and copper on the uptake of different mineral nutrients in the leaves of two cultivars of Brassica napus

\begin{tabular}{llllllll}
\hline Treatment & Cultivar & \multicolumn{3}{l}{ Toxicity ratio $\left(T_{\text {obs }} / T_{\text {pre }}\right)^{\mathrm{a}}$} & & \\
\cline { 3 - 7 } & & $\mathrm{K}$ & $\mathrm{Ca}$ & $\mathrm{Mg}$ & $\mathrm{Fe}$ & $\mathrm{Zn}$ & $\mathrm{Mn}$ \\
\hline $50 \mu \mathrm{M} \mathrm{Cd}+50 \mu \mathrm{M} \mathrm{Cu}$ & Zheda 622 & $0.77 \pm 0.15 \mathrm{a}$ & - & - & $0.99 \pm 0.13 \mathrm{a}$ & $0.92 \pm 0.15 \mathrm{a}$ & $0.77 \pm 0.17 \mathrm{a}$ \\
& ZS 758 & $0.82 \pm 0.17 \mathrm{a}$ & - & - & $0.98 \pm 0.14 \mathrm{a}$ & $1.01 \pm 0.16 \mathrm{a}$ & $0.72 \pm 0.15 \mathrm{a}$ \\
$200 \mu \mathrm{M} \mathrm{Cd}+200 \mu \mathrm{M} \mathrm{Cu}$ & Zheda 622 & $0.71 \pm 0.12 \mathrm{a}$ & - & - & $1.11 \pm 0.14 \mathrm{a}$ & $0.90 \pm 0.11 \mathrm{a}$ & $0.71 \pm 0.18 \mathrm{a}$ \\
& ZS 758 & $0.78 \pm 0.12 \mathrm{a}$ & - & - & $0.93 \pm 0.08 \mathrm{a}$ & $0.93 \pm 0.10 \mathrm{a}$ & $0.71 \pm 0.15 \mathrm{a}$ \\
\hline
\end{tabular}

Data are mean \pm SD of at least three independent replicates. Values within column followed by the same letter are not significantly different by Duncan's multiple range test $(P<0.05)$

- Indicates that $\mathrm{Ca}$ and $\mathrm{Mg}$ did not show any interactive efforts at combined $\mathrm{Cd}$ and $\mathrm{Cu}$ treatments

${ }^{\text {a }}$ Toxic effects of metals mixture were measured experimentally $\left(T_{\text {obs }}\right)$ and were predicted with Abbot's model $\left(T_{\text {pre }}\right) . T_{\text {obs }} / T_{\text {pre }}$ value $=1$ indicated additivity of $\mathrm{Cd}$ and $\mathrm{Cu}$ individual effects, value $>1$ synergism and value $<1$ antagonism

stronger synergism was recorded in the sensitive cultivar Zheda 622 than the tolerant cultivar ZS 758, which was ascribed to the genotypic difference in their ability to modulate the intracellular activity of metals ions. However, $\mathrm{Cd}$ and $\mathrm{Cu}$ synergistic toxicity was noted on plant growth and oxidative stress, while their joint effects were characterized by additively or antagonism.

Acknowledgments This study was supported by the National High Technology Research and Development Program of China (2013AA103007), Jiangsu Collaborative Innovation Center for Modern Crop Production, Special Fund for Agro-scientific Research in the Public Interest (201303022), National Natural Science Foundation of China (31570434), the Science and Technology Department of Zhejiang Province (2012C12902-1), and China Postdoctoral Science Foundation (2015M570512).

\section{References}

Ali S, Zeng FR, Qiu BY, Cai SG, Qiu L, Wu FB, Zhang GP (2011) Interactive effects of aluminum and chromium stresses on the uptake of nutrients and the metals in barley. Soil Sci Plant Nutr 57(1):68-79

Ali B, Huang CR, Qi ZY, Ali S, Daud MK, Geng XX, Liu HB, Zhou WJ (2013a) 5-Aminolevulinic acid ameliorates cadmium-induced morphological, biochemical and ultrastructural changes in seedlings of oilseed rape. Environ Sci Pollut Res 20:7256-7267

Ali B, Tao Q, Zhou Y, Gill RA, Ali S, Rafiq MT, Xu L, Zhou WJ (2013b) 5-Aminolevulinic acid mitigates the cadmium-induced changes in Brassica napus as revealed by the biochemical and ultra-structural evaluation of roots. Ecotoxicol Environ Saf 92:271-280

Ali B, Qian P, Jin R, Ali S, Khan M, Aziz R, Tian T, Zhou W (2014) Physiological and ultra-structural changes in Brassica napus seedlings induced by cadmium stress. Biol Plant 58(1):131-138

Al-Subu MM, Salim R, Douleh A, Atallah A (1993) Combined effects of cadmium, lead and copper on the growth and on metal uptake of broad beans, carrots, radishes and marrow vegetables. Rev Int Contam Ambient 9(1):1-9

An YJ, Kim YM, Kwon TI, Jeong SW (2004) Combined effect of copper, cadmium, and lead upon Cucumis sativus growth and bioaccumulation. Sci Total Environ 326:85-93

Andres-Colas N, Perea-Garcia A, Puig S, Penarrubia L (2010) Deregulated copper transport affects Arabidopsis development especially in the absence of environmental cycles. Plant Physiol 153:170-184

Andresen E, Küpper H (2013) Cadmium toxicity in plants. Met Ions Life Sci 11:395-413

Belimov AA, Safronova VI, Tsyganov VE, Borisov AY, Kozhemyakov AP, Stepanok VV, Martenson AM, Gianinazzi-Pearson V, Tikhonvich IA (2003) Genetic variability in tolerance to cadmium and accumulation of heavy metals in pea (Pisum sativum L.). Euphytica 131:25-35

Burkhead J, Reynolds K, Abdel-Ghany S, Cohu C, Pilon M (2009) Copper homeostasis. New Phytol 182:799-816

Burton KW, Morgan E, Roig A (1986) Interactive effects of cadmium, copper and nickel on the growth of sikta spruce and studies of metal uptake from nutrient solutions. New Phytol 108:549-557

Cuypers A, Smeets K, Ruytinx J, Opdenakker K, Keunen E, Remans T, Horemans N, Vanhoudt N, van Sanden S, van Belleghem F, Guisez Y, Colpaert J, Vangronsveld J (2011) The cellular redox state as a modulator in cadmium and copper responses in Arabidopsis thaliana seedlings. J Plant Physiol 168:309-316

Cuypers A, Keunen E, Bohler S, Jozefczak M, Opdenakker K, Gielen $\mathrm{H}$, Vercampt H, Bielen A, Schellingen K, Vangronsveld J, Remans T (2012) Cadmium and copper stress induce a cellular oxidative challenge leading to damage versus signalling. In: Gupta DK, Sandalio LM (eds) Metal toxicity in plants: perception, signaling and remediation. Springer, Berlin, pp 65-90

Davis RD, Becker PHT (1978) Upper critical levels of toxic elements in plants: II. Critical levels of copper in young barley, wheat, rape, lettuce and rye grass, and of nickel and zinc in young barley and rye grass. New Phytol 80:23-32

de López-Camelo GL, de Miguez RS, Marbán L (1997) Heavy metals input with phosphate fertilizers used in Argentina. Sci Total Environ 204(3):245-250

Farooq MA, Li L, Ali B, Gill RA, Wang J, Ali S, Gill MB, Zhou WJ (2015) Oxidative injury and antioxidant enzymes regulation in arsenic-exposed seedlings of four Brassica napus L. cultivars. Environ Sci Pollut Res 22:10699-10712

Franklin NM, Stauber JL, Lim RP, Petocz P (2002) Toxicity of metal mixtures to a tropical freshwater alga (Chlorella sp.): the effect of interactions between copper, cadmium, and zinc on metal cell binding and uptake. Environ Toxicol Chem 21:2412-2422

Ghasemi R, Ghaderian SM, Krämer U (2009) Interference of nickel with copper and iron homeostasis contributes to metal toxicity symptoms in the nickel hyperaccumulator plant Alyssum inflatum. New Phytol 184:566-580

Gill SS, Tuteja N (2010) Reactive oxygen species and antioxidant machinery in abiotic stress tolerance in crop plants. Plant Physiol Biochem 48:909-930 
Gill RA, Zang LL, Ali B, Farooq MA, Cui P, Yang S, Ali S, Zhou WJ (2015) Chromium-induced physio-chemical and ultrastructural changes in four cultivars of Brassica napus L. Chemosphere 120:154-164

Gisi U (1996) Synergistic interaction of fungicides in mixtures. Phytopathology 86:1273-1279

Gondar D, López R, Fiol S, Antelo JM, Arce F (2006) Cadmium, lead, and copper binding to humic acid and fulvic acid extracted from an ombrotrophic peat bog. Geoderma 135:196-203

Guo T, Zhang GP, Zhou M, Wu F, Chen JX (2004) Influence of aluminum and cadmium stresses on mineral nutrition and root exudates in two barley cultivars. Pedosphere 17(4):505-512

Guo TR, Zhang GP, Zhang YH (2007) Physiological changes in barley plants under combined toxicity of aluminum, copper and cadmium. Colloid Surface B 57(2):182-188

Heath RL, Packer L (1968) Photoperoxidation in isolated chloroplasts: I. Kinetics and stoichiometry of fatty acid peroxidation. Arch Biochem Biophys 125:189-198

Huang Y, Hu Y, Liu Y (2009) Combined toxicity of copper and cadmium to six rice genotypes (Oryza sativa L.). J Environ Sci 21:647-653

Islam MK, Khanam S, Lee SY, Waghmode TR, Alam I, Huh MR (2015) Interactive effects of arsenic and chromium stresses on mineral and metal uptake in jute (Corchorus olitorius L.). POJ $8(3): 220-231$

Jiang M, Zhang J (2001) Effect of abscisic acid on active oxygen species, antioxidative defence system and oxidative damage in leaves of maize seedlings. Plant Cell Physiol 42:1265-1273

Kabata-Pendias A (2011) Trace elements in soils and plants, 4th edn. CRC Press, Boca Raton

Kikuchi T, Okazaki M, Toyota K, Motobayashi T, Kato M (2007) The input-output balance of cadmium in a paddy field of Tokyo. Chemosphere 67:920-927

Kuboi T, Noguchi A, Yazaki J (1987) Relationship between tolerance and accumulation characteristics of cadmium in higher plants. Plant Soil 104:275-280

Lachman J, Dudjak J, Miholova D, Kolihova D, Pivec V (2004) Effect of cadmium stress on the uptake and distribution of microelements copper and zinc in plants parts of barley (Horderum sativum L.). SAB 35(3):81-86

Lichtenthaler H, Wellburn A (1983) Determination of total carotenoids and chlorophyll $\mathrm{a}$ and $\mathrm{b}$ of leaf extracts in different solvents. Biochem Soc Trans 11:591-592

Lidon FC, Henriques FS (1992) Copper toxicity in rice: a diagnostic criteria and its effect on $\mathrm{Mn}$ and Fe contents. Soil Sci 154(2):130-135

Lin Y-F, Aarts GM (2012) The molecular mechanism of zinc and cadmium stress response in plants. Cell Mol Life Sci 69:3187-3206

Lin S-L, Wu L (1994) Effects of copper concentration on mineral nutrient uptake and copper accumulation in protein of coppertolerant and nontolerant Lotus purshianus L. Ecotoxicol Environ Saf 29(2):214-228

Liu Y, Vijver MG, Qiu H, Baas J, Peijnenburg W (2015) Statistically significant deviations from additivity: What do they mean in assessing toxicity of mixtures? Ecotoxicol Environ Saf 122:37-44

Momoh E, Zhou W (2001) Growth and yield responses to plant density and stage of transplanting in winter oilseed rape (Brassica napus L.). J Agron Crop Sci 186:253-259

Nagajyoti PC, Lee KD, Sreekanth TVM (2010) Heavy metals, occurrence and toxicity for plants: a review. Environ Chem Lett 8:199-216

Nishizono H, Ichikawa H, Suziki S, Ishii F (1987) The role of the root cell wall in the heavy metal tolerance of Athyrium yokoscense. Plant Soil 101:15-20

Oliveira LM, Ma LQ, Santos JA, Guilherme LR, Lessl JT (2014) Effects of arsenate, chromate, and sulfate on arsenic and chromium uptake and translocation by arsenic hyperaccumulator Pteris vittata L. Environ Pollut 184:187-192

Qian H, Li J, Pan X, Sun L, Lu T, Ran H, Fu Z (2009) Combined effect of copper and cadmium on heavy metals ions accumulation and antioxidative induction in Chlorella vulgaris. Bull Environ Contam Toxicol 87:512-516

Ravet K, Pilon M (2013) Copper and iron homeostasis in plants: the challenges of oxidative stress. Antioxid Redox Signal 19:919-932

Smith SR (2009) A critical review of the bioavailability and impacts of heavy metals in municipal solid waste composts compared to sewage sludge: Review article. Environ Int 35:142-156

Spurgeon DJ, Jones MAH, Dorne J-L, Svendsen C, Swain S, Stürzenbaum SR (2010) Systems toxicology approaches for understanding the joint effects of environmental chemical mixtures. Sci Total Environ 408:3725-3734

Teisseire H, Couderchet M, Vernet G (1999) Phytotoxicity of diuron alone and in combination with copper or folpet on duckweed (Lemna minor). Environ Pollut 106:39-45

Valko M, Morris H, Cronin MT (2005) Metals, toxicity and oxidative stress. Curr Med Chem 12:1161-1208

Velikova V, Edreva A, Loreto F (2004) Endogenous isoprene protects Phragmites australis leaves against singlet oxygen. Physiol Plant 122:219-225

Verbruggen N, Hermans C, Schat H (2009) Mechanisms to cope with arsenic or cadmium excess in plants. Curr Opin Plant Biol 12:1-9

Wei B, Yang L (2010) A review of heavy metal contaminations in urban soils, urban road dusts and agricultural soils from China. Microchem J 9:99-107

Wong MK, Chuah GK, Ang KP, Koh LL (1986) Interactive effects of lead, cadmium and copper combinations in the uptake of metals and growth of Brassica chinensis. Environ Exp Bot 26(4):331-339

Wu FB, Zhang GP (2002) Genotypic differences in effect of Cd on growth and mineral concentrations in barley seedlings. Bull Environ Contam Toxicol 69:219-227

Wu J, Mo LY, Qin LT, Zhu ZQ, Zhu YN (2014) Research advancement of the joint toxicity of heavy metals mixture. Appl Mech Mater 522-524:532-536

Wuana RA, Okieimen FE (2011) Heavy metals in contaminated soils: a review of sources, chemistry, risks and best available strategies for remediation. Int Sch Res Netw ISRN Ecol. doi:10.5402/ $2011 / 402647$

Yadav SK (2010) Heavy metals toxicity in plants: an overview on the role of glutathione and phytochelatins in heavy metal stress tolerance of plants. S Afr J Bot 76:167-179

Yadav S, Srivastava J (2014) Phytoremediation of cadmium toxicity by Brassica spp.: a review. Int. J Biol Sci 3(5):47-52

Yu RL, Ji J, Yuan X, Song Y, Wang C (2012) Accumulation and translocation of heavy metals in the canola (Brassica napus L.) soil system in Yangtze river delta, China. Plant Soil 353:33-45

Žaltauskaite J, Šliumpaite I (2013) Single and combined toxicity of copper and cadmium to Horderum vulgare growth and heavy metal bioaccumulation. In: E3S Web of conferences, vol 1, p 15013. doi:10.1051/e3sconf/20130115013

Zeng F, Qiu B, Wu X, Niu S, Wu FB, Zhang GP (2012) Glutathionemediated alleviation of chromium toxicity in rice plants. Biol Trace Elem Res 148:255-263

Zhou WJ (2001) Oilseed rape. In: Zhang GP, Zhou WJ (eds) Crop production. Zhejiang University Press, Hangzhou, pp 153-178

Zhou Z, Zhou J, Li R, Wang H, Wang J (2007) Effect of exogenous amino acids on $\mathrm{Cu}$ uptake and translocation in maize seedlings. Plant Soil 292:105-117 